\begin{tabular}{|l|l|l||}
\hline \multicolumn{2}{|c|}{ PublisherInfo } \\
\hline \hline PublisherName & $:$ & BioMed Central \\
\hline \hline PublisherLocation & $:$ & London \\
\hline \hline PublisherImprintName & $:$ & BioMed Central \\
\hline \hline
\end{tabular}

\title{
Activation by an HDAC
}

\begin{tabular}{|l|l|l||}
\hline \multicolumn{2}{|c|}{ ArticleInfo } \\
\hline \hline ArticleID & $:$ & 4638 \\
\hline \hline ArticleDOI & $:$ & $10.1186 /$ gb-spotlight-20021119-01 \\
\hline \hline ArticleCitationID & $:$ & spotlight-20021119-01 \\
\hline \hline ArticleSequenceNumber & $:$ & 304 \\
\hline \hline ArticleCategory & $:$ & Research news \\
\hline ArticleFirstPage & $:$ & 1 \\
\hline \hline ArticleLastPage & $:$ & 2 \\
\hline \hline & & RegistrationDate : 2002-11-19 \\
ArticleHistory & $:$ & OnlineDate \\
\hline \hline ArticleCopyright & $:$ & BioMed Central Ltd2002-11-19 \\
\hline \hline ArticleGrants & $:$ & \\
\hline \hline ArticleContext & $:$ & 130593311 \\
\hline \hline
\end{tabular}




\section{Jonathan B Weitzman}

Email: jonathanweitzman@hotmail.com

Histone deacetylases are generally thought of as repressors of gene activity. In the November 15 Science, Amy Wang and colleagues report that the Hos2 histone deacetylase from the yeast Saccharomyces cerevisiae can in fact induce gene activity (Science, 298:1412-1414, November 15, 2002). Chromatin immunoprecipitation (ChIP) techniques, using specific antibodies to sites of acetylation in all four core histones, were applied to screen for genes whose chromatin is hyperacetylated in mutants lacking Hos2 or the related Rpd3 histone deacetylase. Hos2 showed a unique histone specificity and was preferentially required for $\mathrm{H} 3$ and $\mathrm{H} 4$ deacetylation on some genes. Hos 2 deacetylation of H4-K12 was associated with transcriptional activation of the GAL genes in galactose conditions. Hos2 ChIP was combined with microarray hybridization to demonstrate that Hos2 associates with the coding regions of active genes genome-wide. Set3, a factor associated with Hos2, was also required for efficient transcription.

\section{References}

1. Histone deacetylase activity of Rpd3 is important for transcriptional repression in vivo.

2. Science., [http://www.sciencemag.org] 